\title{
The Sources of Revenues for Wisconsin Native American Casinos: Implications for Casino Gaming as a Regional Economic Development Tool
}

Ricardo Gazel, Dan S. Rickman, and William N. Thompson*

\begin{abstract}
This paper ascertains the sources of revenues for Native American casinos in Wisconsin. Based on an examination of the sources, implications for casino gaming as a statewide economic development tool are discussed. The analysis is based on interviews of visitors to several casinos in 1994. Among the findings are that: noncasino areas in Wisconsin experience a net loss of funds to areas containing the casinos; expenditures in other businesses in the areas containing the casinos are likely displaced; and lower-income individuals and the unemployed are more adversely affected by the availability of casino gambling in the state than others.
\end{abstract}

\section{INTRODUCTION}

Casino gambling has increasingly been proposed as a tool for economic development and a means of generating additional tax revenue (for discussion see Madhusudhan 1996; Mason and Stranahan 1996; Blevins and Jensen 1998; Gross 1998). In 1996, gambling taxes totaled $\$ 16.8$ billion and gambling was estimated to be responsible for about 460,000 jobs nationwide, with an estimated $\$ 1$ of every $\$ 10$ spent on leisure for gambling (Christiansen 1998). Despite its rapid expansion, a lack of balanced approaches to assessing the economics of casino gambling had been noted early on (Goodman 1994). (For a brief history of the expansion of casino gambling, see Eadington 1999.)

Nevertheless, the economic impact of casino gambling has begun to receive considerable attention in the academic literature (e.g., Grinols 1994; Gazel, Thompson, and Rickman 1995; Persky 1995; Rephann et al. 1997; Gazel 1998; Walker and Jackson 1998). Correspondingly, a literature has emerged on the impact on crime of casino gambling (e.g., Friedman, Hakim, and Weinblatt 1989; Giacopassi and Still 1993; Hsing 1996; Miller and Schwartz 1998) and the social costs of compulsive or pathological gambling (e.g., Thompson, Gazel, and

\footnotetext{
* Inter-American Development Bank, Washington, D.C.; Professor of Economics and OG\&E Chair in Regional Economic Analysis, Oklahoma State University, Stillwater, OK; and Professor of Public Administration, College of Urban Affairs, University of Nevada, Las Vegas. The authors acknowledge the help of Suzanne Ulrich in managing the team that conducted the survey utilized in this paper. Thompson also received support funding for the study from the Wisconsin Policy Research Institute in Milwaukee. This study could not have been possible without the cooperation of the Oneida and Potawatomi tribes of Wisconsin. They gave our research team access to gaming facilities so that we could interview their players. The views and conclusions in this paper are those of the researchers, and in no way should any tribal official be considered to have endorsed them. The views expressed herein are solely those of the authors and do not necessarily reflect the views of the Inter-American Development Bank.
} 
Rickman 1997; Lesieur 1998). In a unique vein, Blair, Schwer, and Waddoups (1998) examine the issue of worker satisfaction in the gaming industry as it relates to economic development.

However, although sometimes acknowledged, fewer attempts have been made to examine the sources of casino revenues and their effects on the distribution of income across areas, businesses, and people within the state. For example, areas within the state containing casino gambling may benefit at the expense of other areas that do not contain casino gambling. From a statewide policy-making perspective, these area income shifts represent no net gain to the state. Similarly, questions arise as to how area businesses are affected by casino gambling. Standard multiplier theory suggests that there will be indirect and induced spending effects that benefit area businesses. Yet, casino gambling by area residents may be substituting for other expenditures (e.g., Przybylski et al. 1998), producing negative spending effects in certain sectors. As Henriksson (1996) notes, to assess the equity aspects of casino gambling, particular consideration must be given to the effects on area businesses competing for the same money. In addition, who are the gamblers and how is the distribution of household income affected by casino gambling? Studies have found that gambling taxes are regressive (e.g., Mason, Shapiro, and Borg 1989; Borg, Mason, and Shapiro 1991; Rivenbark 1998). Socioeconomic status was found to be associated with casino gambling in Australia by Boreham, Dickerson, and Harley (1996) and Layton and Worthington (1999). Differences in the demographic makeup of gamblers between Atlantic City and Las Vegas were reported by Borg, Mason, and Shapiro (1990).

Therefore, this study attempts more fully to address the resource-shifting and income-distribution aspects of casino gambling as a tool of economic development. Although there are probable gains in consumer surplus from gambling consumption, like there are from the availability of any other good or service, these are often discounted because of the moral criticism that gambling receives (Eadington 1999). Proponents of legalized gambling often then point to the potential economic development or tax benefits of gambling.

The study is based on interviews of visitors to Wisconsin Native American casinos. We do not estimate the economic benefits to Native Americans of casino gambling, as it has been previously established that there are significant benefits (Gazel, Thompson, and Rickman 1995; Anders 1996; d'Hauteserre 1998). Rather, we examine changes in visitor household budget allocations attributable to casino gambling in the state. These include substitution of casino gambling for consumption of other goods and services by both area residents on items such as necessities, and by Wisconsin residents from noncasino areas and nonresidents in the form of reduced expenditures on other tourist-related activities. For example, Anders, Siegel, and Yacoub (1998) report that Indian casinos may divert funds from taxable to nontaxable sectors such that state tax revenues may be reduced, while Przybylski et al. (1998) found evidence that gambling displaces tourist demand. Correspondingly, we consider how gambling affects savings. We also 
focus on the socioeconomic composition of casino gamblers and the impact on the distribution of income.

\section{SURVEY METHODOLOGY}

The data used in the analysis are based on casino-site interviews of gamblers randomized by location, season, time of day, and day of week, as well as through a process of alternating persons selected. A first round of surveys was conducted at two locations on different days: on August 30, 1994, 77 players were interviewed at Carter; and on September 2, 1994, 145 were interviewed in Milwaukee. Players were selected in alternating order and asked if they would participate in the survey. For their effort, they were given a $\$ 2$ coupon toward the purchase of any item at the snack shop or gift shop. The survey took players approximately ten minutes to complete. A second round of interviews resulted in completed surveys of 121 at Carter, 166 in Milwaukee, and 186 in Green Bay. In Green Bay, 69 cars were counted on August 31, 1994, and 1,046 cars were counted on September 3, 1994. During the second round of interviews, 192 cars were counted at the Ho Chunk casino in Baraboo on October 28, 1994. On November 2, 1994, 55 cars were counted at Mole Lake (2 casinos), 98 cars were counted at Bowler, and 34 cars were counted at Lac du Flambeau. Survey questions used for the analysis in this paper are presented in the Appendix, while a complete description of the methodology and survey results are available from the authors upon request.

\section{REVENUE SOURCES AND DEMOGRAPHIC PATTERNS OF CASINO GAMBLING}

As discussed above, most economic impact studies do not carefully consider the sector and household income distribution of the economic impacts of casino gambling. Therefore, to examine these impacts, we asked questions regarding the effects of casino gambling on visitor expenditures on other goods and services and on savings. We also collected data on visitor characteristics.

We rely on regression analysis to look for patterns in responses to the survey questions across respondents. Some expenditures may be more substitutable for casino gambling than others, and these substitutions may differ by group. In addition, which groups gamble more often and spend more at the casinos is examined. Particular emphasis is given to how the existence of casino gambling in the state affects economic decisions of different demographic groups. Independent variables included in the regressions account for differences in responses according to: (1) demographic characteristics; (2) whether the person is unemployed; (3) whether the person is retired; (4) the income of the individual; (5) the distance traveled to the casino; and (6) whether the person lives in Wisconsin. Since different types of survey questions were asked, alternative regression techniques are utilized in the analysis where appropriate. 


\section{Descriptive Statistics}

Summary statistics for the survey questions used in this study are given in Table 1. From Table 1, we see that most visitors were female and Caucasian, with an average age of 57 . We also see that females and those older than 64 years of age were overrepresented among the visitors in comparison to their proportions in the general population. In fact, the percentages of females among visitors who were less than 65 years of age, and those who were greater than or equal to 65 years of age, were about the same (not shown). African Americans and Native Americans also were overrepresented among the visitors to the casinos, while Caucasians were underrepresented. Corresponding with the age profile of the visitors, almost 37 percent of the visitors were retired. The median income reported was in the $\$ 25,000-\$ 35,000$ range, with the high end of the range being slightly below median household income in the general population.

\section{TABLE 1}

Statistical Summary of Survey Responses*

\begin{tabular}{|c|c|c|}
\hline Category & Sample & Population \\
\hline \%Female & 62.6 & 51.1 \\
\hline Average Age & 57.4 & 35.1 \\
\hline$\%>64$ years old & 29.1 & 13.3 \\
\hline \%Caucasian & 84.4 & 90.3 \\
\hline \%African American & 8.0 & 5.4 \\
\hline$\%$ Native American & 5.6 & 0.9 \\
\hline Median Income Range (\$1000s) & $25-35$ & 35.4 \\
\hline \%Unemployed & 2.1 & \\
\hline$\%$ Retired & 36.5 & \\
\hline$\%$ Distance (<50 miles) & 50.0 & \\
\hline \%Distance (50-100 miles) & 23.0 & \\
\hline \%Distance (Over 100 miles) & 27.0 & \\
\hline$\%$ Out-of-State & 20.2 & \\
\hline Frequency of Visits (visits/year) & 54.8 & \\
\hline \%First Visit & 10.4 & \\
\hline$\%$ Primary Purpose & 77.3 & \\
\hline$\%$ Visit if No Casino & 41.2 & \\
\hline Average Gambling Expenditure & $\$ 101.2$ & \\
\hline Average Spent Shopping in Casino & $\$ 1.2$ & \\
\hline Average Spent Food \& Beverage in Casino & $\$ 8.9$ & \\
\hline Average Spent Lodging & $\$ 10.5$ & \\
\hline Average Spent Food \& Beverage/Noncasino & $\$ 4.7$ & \\
\hline Average Other Expenditures & $\$ 5.5$ & \\
\hline$\%$ Save More & 22.6 & \\
\hline \%Buy More Groceries & 7.8 & \\
\hline \%Buy More Clothes & 20.5 & \\
\hline$\%$ Visit Other Casinos & 40.1 & \\
\hline \%Other Travel & 32.9 & \\
\hline \%Dine Out More Often & 29.5 & \\
\hline \%Go to More Movies & 14.6 & \\
\hline
\end{tabular}

"Average age and \% > 64 years old are from the 1990 Census of Population, while the remaining variables are for 1994 and were obtained from the 1997 U.S. Statistical Abstract.

The average frequency of visits exceeded once per week during the previous year. Figure 1 displays the cumulative frequency distribution of visits in a manner similar to that of a Lorenz Curve of income inequality. From Figure 1, we 
see that the distribution is skewed towards a lower frequency of visits per year and the maximum number of visits reported is 260 . One-half of all visitors lived within 50 miles of the casino, while only 20 percent were from out-of-state. While the out-of-state visitors may have brought new money to the state, the remaining percentages of visitors from within the state suggest that expenditures on other goods and services within the local area and state were affected.

\section{FIGURE 1}

Frequency of Visits Histogram

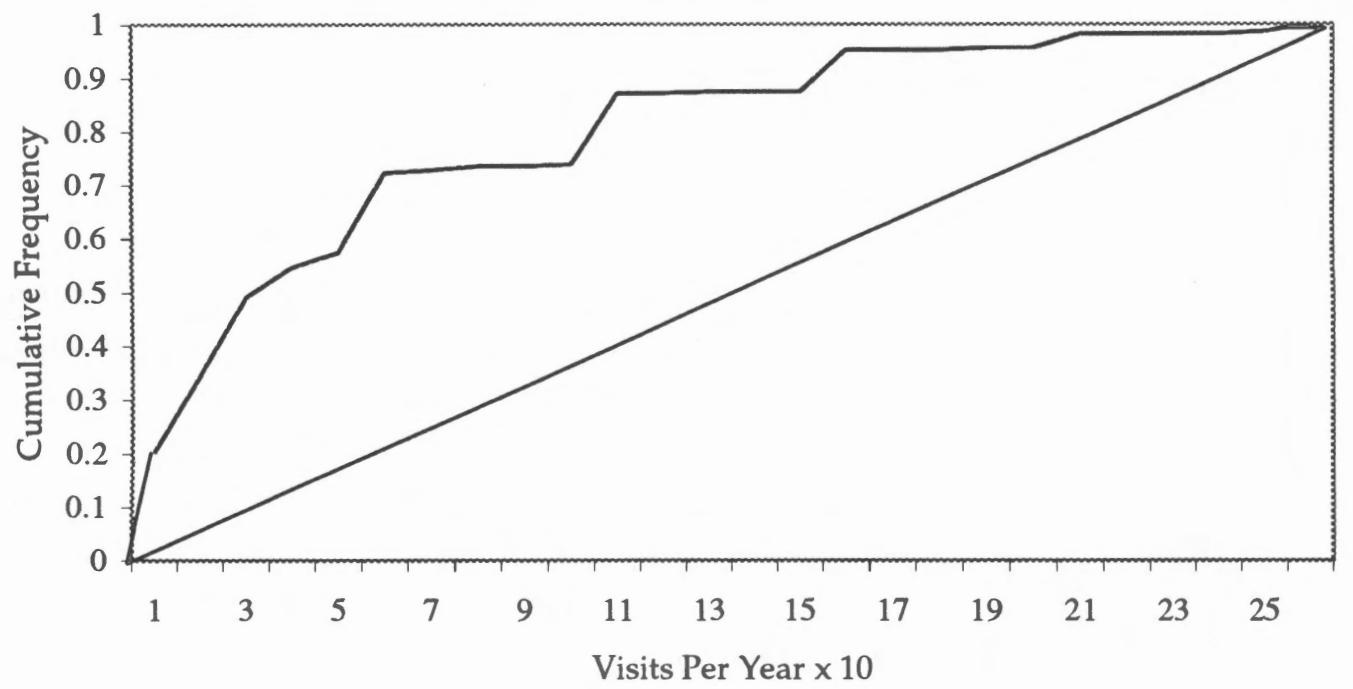

Table 2 shows the relationship between frequency of visits and distance to the casino. Of those surveyed, 20.5 percent reported visiting the casino less than once a month, 37 percent visited once a month or more but less than once per week, and 42.6 percent visited once a week or more. Boreham, Dickerson, and Harley (1996) reported lower frequency of visitation to Australian casinos: about one-half played less than once every two months. Frequency of visits is negatively carrelated with distance. Those who lived within 35 miles of the casino comprised 41.5 percent of all visitors, while they were 53.9 percent of those who visited once a week or more. Similarly, while those who lived more than 100 miles from the casino made up 22.2 percent of all visitors, they comprised 44.4 percent of those who visited less than once a month.

TABLE 2

Cross Tabulation Table of Distance $x$ Frequency of Visits (percent of total in parentheses)*

\begin{tabular}{lcccc}
\hline Distance $\backslash$ Frequency & $<12$ per year & $12-51$ per year & $\geq 52$ per year & Total \\
\hline$<35$ miles & 26 & 80 & 131 & $237(41.5)$ \\
$35-49$ miles & 6 & 27 & 39 & $72(12.6)$ \\
$50-100$ miles & 33 & 50 & 52 & $135(23.6)$ \\
$>100$ miles & 52 & 54 & 21 & $127(22.2)$ \\
\hline Total & $117(20.5)$ & $211(37.0)$ & $243(42.6)$ & $571(100)$ \\
\hline
\end{tabular}

*Sums may not equal 100 due to rounding. 
Table 3 shows the relationship between frequency of visits and income. Those earning $\$ 20,000$ or less per year comprised 29.4 percent of all visitors and 39.1 percent of those who visited once a week or more. Correspondingly, those earning $\$ 60,000$ or more made up 12.8 percent of all visitors and only 6 percent of those who visited once a week or more.

TABLE 3

Cross Tabulation Table of Annual Income $x$ Frequency of Visits (percent of total in parentheses)

\begin{tabular}{lcccc}
\hline Income $\backslash$ Frequency & $<12$ per year & $12-51$ per year & $\geq 52$ per year & Total \\
\hline$<\$ 20,000$ & 22 & 46 & 91 & $159(29.4)$ \\
$\$ 20,000-\$ 39,999$ & 47 & 84 & 97 & $228(42.1)$ \\
$\$ 40,000-\$ 59,999$ & 17 & 37 & 31 & $85(15.7)$ \\
$\$ 60,000-\$ 79,999$ & 11 & 22 & 13 & $46(8.5)$ \\
$\geq \$ 80,000$ & 9 & 13 & 1 & $23(4.3)$ \\
\hline Total & $106(19.6)$ & $202(37.3)$ & $233(43.1)$ & $541(100)$ \\
\hline
\end{tabular}

Table 1 also contains summary statistics for various expenditure decisions and budget reallocations associated with casino gambling. The average gambling expenditure was about $\$ 100$. Over three-fourths of the respondents indicated that the primary purpose of the visit to the area was to gamble at the casino, and over 40 percent reported that they would still visit the area if there were no casino. Consistent with the findings of Grinols and Omorov (1996) for Illinois, and Boreham, Dickerson, and Harley (1996) for Australia, expenditures on other goods and services were reduced because of the availability of casino gambling in the state.

Nearly 8 percent reported that their purchases of groceries were reduced, and over 20 percent reported reducing their purchases of clothes. About 30 percent reported that they would dine out more often and about 15 percent said that they would go to more movies in the absence of casino gambling. Almost onethird indicated that they would travel elsewhere, and over 40 percent said that they would visit other casinos in the absence of the casino that they were visiting when interviewed. Finally, over 20 percent of the visitors reported that their savings were reduced because of their casino gambling. Boreham, Dickerson, and Harley (1996) reported that 15.5 percent of those who gambled had their savings reduced.

\section{Visitor Draw of Casinos}

Table 4 contains statistical results related to the importance of the casinos in attracting visitors to the area. Responses to four questions are used to determine patterns in how responsible casinos are for the visitation to the area. The last two rows of Table 4 show the number of valid cases and a summary statistic for the regression. Regarding the number of valid cases, an observation is included in the regression if and only if valid responses were given for each variable included.

The first column of results corresponds to the question of how frequently the individual visited that casino. Because frequency of visitation is a count vari- 
able, a negative binomial regression model is used. An alternative model would be the Poisson model, but it assumes the equality of the mean and variance of the dependent variable, which we test and reject (shown at the bottom of the column).

TABLE 4

Visitor Draw of Casinos

(absolute value of $\mathrm{t}$-statistic in parentheses)

\begin{tabular}{|c|c|c|c|c|}
\hline $\begin{array}{l}\text { Independent/Dependent } \\
\text { Variables }\end{array}$ & $\begin{array}{l}\text { Frequency } \\
\text { of Visits } \\
\text { (NEGBIN) }\end{array}$ & $\begin{array}{l}\text { First Visit } \\
\text { (LOGIT) }\end{array}$ & $\begin{array}{l}\text { Primary } \\
\text { Purpose } \\
\text { (LOGIT) }\end{array}$ & $\begin{array}{c}\text { Visit if No } \\
\text { Casino } \\
\text { (LOGIT) }\end{array}$ \\
\hline Constant & $\begin{array}{c}4.50 \\
(11.66)^{* * *}\end{array}$ & $\begin{array}{l}-2.12 \\
(1.98)^{* *}\end{array}$ & $\begin{array}{c}0.58 \\
(0.50)\end{array}$ & $\begin{array}{c}0.14 \\
(0.13)\end{array}$ \\
\hline Gender $($ Female $=1)$ & $\begin{array}{c}0.09 \\
(0.82)\end{array}$ & $\begin{array}{l}0.86 \\
(2.21)^{* *}\end{array}$ & $\begin{array}{l}-0.18 \\
(0.54)\end{array}$ & $\begin{array}{l}-0.27 \\
(1.02)\end{array}$ \\
\hline Age & $\begin{array}{l}-0.12 E-02 \\
(0.26)\end{array}$ & $\begin{array}{l}-0.20 \\
(1.34)\end{array}$ & $\begin{array}{l}0.04 \\
(3.12)^{* * *}\end{array}$ & $\begin{array}{l}-0.03 \\
(2.33)^{* * *}\end{array}$ \\
\hline Race (Caucasian=1) & $\begin{array}{c}0.02 \\
(0.08)\end{array}$ & $\begin{array}{l}0.17 \\
(0.26)\end{array}$ & $\begin{array}{l}-0.63 \\
(0.70)\end{array}$ & $\begin{array}{c}0.81 \\
(0.92)\end{array}$ \\
\hline Native American & $\begin{array}{l}-0.09 \\
(0.25)\end{array}$ & $\begin{array}{l}-1.40 \\
(1.15)\end{array}$ & $\begin{array}{l}-1.16 \\
(1.15)\end{array}$ & $\begin{array}{l}1.77 \\
(1.79)^{*}\end{array}$ \\
\hline Unemployed & $\begin{array}{l}-0.16 \\
(0.32)\end{array}$ & $\begin{array}{c}0.61 \\
(0.66)\end{array}$ & $\begin{array}{c}0.33 \\
(0.24)\end{array}$ & $\begin{array}{r}-11.29 \\
(0.07)\end{array}$ \\
\hline Retired & $\begin{array}{l}-0.02 \\
(0.12)\end{array}$ & $\begin{array}{l}-0.07 \\
(0.14)\end{array}$ & $\begin{array}{c}0.12 \\
(0.26)\end{array}$ & $\begin{array}{l}0.26 \\
(0.78)\end{array}$ \\
\hline Income & $\begin{array}{l}-0.11 \\
(4.19)^{* * *}\end{array}$ & $\begin{array}{l}-0.09 \\
(1.09)\end{array}$ & $\begin{array}{l}-0.04 \\
(0.53)\end{array}$ & $\begin{array}{l}-0.03 \\
(0.45)\end{array}$ \\
\hline Distance (50-100 miles) & $\begin{array}{l}-0.46 \\
(3.39)^{* * *}\end{array}$ & $\begin{array}{c}0.63 \\
(1.23)\end{array}$ & $\begin{array}{l}-0.04 \\
(0.09)\end{array}$ & $\begin{array}{l}0.25 \\
(0.73)\end{array}$ \\
\hline Distance (Over 100 miles) & $\begin{array}{l}-0.89 \\
(6.48)^{* * *}\end{array}$ & $\begin{array}{l}1.86 \\
(4.21)^{* * *}\end{array}$ & $\begin{array}{l}-1.50 \\
(3.39)^{* * *}\end{array}$ & $\begin{array}{l}0.58 \\
(1.69)^{*}\end{array}$ \\
\hline Out-of-State & $\begin{array}{c}0.14 \\
(0.80)\end{array}$ & $\begin{array}{c}0.27 \\
(0.66)\end{array}$ & $\begin{array}{c}0.23 \\
(0.62)\end{array}$ & $\begin{array}{l}-0.05 \\
(0.16)\end{array}$ \\
\hline $\begin{array}{l}\text { No. Observations } \\
\text { Chi-Squared Statistic/ } \alpha\end{array}$ & $\alpha=1.07^{\mathrm{a}}$ & $\begin{array}{l}494 \\
54.29 \mathrm{~b}\end{array}$ & $\begin{array}{l}298 \\
46.62^{b}\end{array}$ & $\begin{array}{l}296 \\
22.12^{b}\end{array}$ \\
\hline
\end{tabular}

aIndicates statistically significant a, indicating overdispersion and rejection of the Poisson model

$\mathrm{b}$ Indicates statistically significant regression fit below the 0.01 level based on the chi-squared test

*Indicates statistical significance at or below the 0.10 level based on a two-tailed $t$-test.

**Indicates statistical significance at or below the 0.05 level based on a two-tailed t-test.

***Indicates statistical significance at or below the 0.01 level based on a two-tailed t-test.

From the first column, we see that frequency of visitation declines with distance (confirming the results of Table 2). After accounting for distance, being out-of-state is insignificant. Confirming the results of Table 3, income level is negatively related to frequency of visitation, even after controlling for distance traveled and whether the individual was retired or unemployed. Thus, lower-income individuals who live closer are the most frequent visitors. Besides equity concerns for individuals, this also is significant because lower-income visitors who live closer are less likely to spend money on noncasino items, such as lodging (shown later).

In a related question, column two examines patterns among those who report that it is their first visit. Since the dependent variable either equals zero or one, a logit regression was estimated. Positive coefficient values indicate increased $\log$ odds of the dependent variable having a value of unity (i.e., the first visit). 
The results suggest that females and those who traveled the farthest are more likely to report that it is their first visit. So, although females were the majority of visitors, they were less likely to have been repeat customers. Being from out-ofstate was not significant once distance was accounted for. Income level and the remaining variables were insignificant.

The third column of results examines whether visiting the casino was the primary purpose of the trip. Age was positively related to casino gambling being the primary purpose of the visit to the area. On the other hand, those who traveled the farthest were least likely to report that the casino was the primary purpose of the trip. Therefore, expenditures in the area by individuals who traveled more than 100 miles are less attributable to the availability of casino gambling than those made by visitors who live nearby. Correspondingly, column four shows that younger individuals who traveled over 100 were more likely still to visit the area if no casino existed. These results might be explained as younger families being more likely to visit the area as part of a vacation, with casinos only an added activity. Relative to others, there are reasons other than casino gambling for these individuals, who spend relatively more on noncasino items than others, to visit the area. Thus, their expenditures in the area should not be attributed solely

TABLE 5

Casino Spending (absolute value of t-statistic in parentheses)

\begin{tabular}{|c|c|c|c|c|}
\hline \multirow[t]{2}{*}{$\begin{array}{l}\text { Independent/Dependent } \\
\text { Variables }\end{array}$} & \multirow[t]{2}{*}{$\begin{array}{l}\text { Gambling } \\
\text { (OLS) }\end{array}$} & \multirow[t]{2}{*}{$\begin{array}{l}\text { Shopping } \\
\text { (OLS) }\end{array}$} & \multicolumn{2}{|c|}{$\begin{array}{c}\text { Food \& Beverage } \\
\text { (TOBIT) }\end{array}$} \\
\hline & & & Coefficient & Slope \\
\hline Constant & $\begin{array}{l}28.27 \\
(0.74)\end{array}$ & $\begin{array}{l}5.27 \\
(4.17)^{* * *}\end{array}$ & $\begin{array}{l}-3.72 \\
(0.42)\end{array}$ & \\
\hline Gender $($ Female $=1)$ & $\begin{array}{c}-14.42 \\
(1.13)\end{array}$ & $\begin{array}{l}-0.89 \\
(2.06)^{* *}\end{array}$ & $\begin{array}{l}-1.23 \\
(0.41)\end{array}$ & -0.87 \\
\hline Age & $\begin{array}{c}0.27 \\
(0.49)\end{array}$ & $\begin{array}{l}-0.02 \\
(1.20)\end{array}$ & $\begin{array}{c}0.04 \\
(0.28)\end{array}$ & 0.03 \\
\hline Race (Caucasian=1) & $\begin{array}{c}2.63 \\
(0.11)\end{array}$ & $\begin{array}{l}-2.41 \\
(2.98)^{* * *}\end{array}$ & $\begin{array}{c}0.44 \\
(0.08)\end{array}$ & 0.14 \\
\hline Native American & $\begin{array}{l}-9.37 \\
(0.29)\end{array}$ & $\begin{array}{l}-3.35 \\
(3.04)^{* * *}\end{array}$ & $\begin{array}{l}8.60 \\
(1.11)\end{array}$ & 6.10 \\
\hline Retired & $\begin{array}{l}-6.82 \\
(0.41)\end{array}$ & $\begin{array}{l}-0.18 \\
(0.33)\end{array}$ & $\begin{array}{l}-2.40 \\
(0.61)\end{array}$ & -1.70 \\
\hline Unemployed & $\begin{array}{l}88.65 \\
(2.09)^{* *}\end{array}$ & $\begin{array}{l}1.99 \\
(1.40)\end{array}$ & $\begin{array}{l}-2.64 \\
(0.26)\end{array}$ & -1.87 \\
\hline Income & $\begin{array}{l}12.52 \\
(4.40)^{* * * *}\end{array}$ & $\begin{array}{l}-0.04 \\
(0.81)\end{array}$ & $\begin{array}{c}0.67 \\
(0.98)\end{array}$ & 0.48 \\
\hline Distance (50-100 miles) & $\begin{array}{l}-8.78 \\
(0.56)\end{array}$ & $\begin{array}{l}-0.44 \\
(0.81)\end{array}$ & $\begin{array}{l}-0.22 \\
(0.06)\end{array}$ & -0.16 \\
\hline Distance (Over 100 miles) & $\begin{array}{l}22.40 \\
(1.38)\end{array}$ & $\begin{array}{l}-0.51 \\
(1.04)\end{array}$ & $\begin{array}{l}3.95 \\
(1.01)\end{array}$ & 2.80 \\
\hline Out-of-State & $\begin{array}{l}41.88 \\
(2.94)^{* * *}\end{array}$ & $\begin{array}{l}0.90 \\
(1.83)^{*}\end{array}$ & $\begin{array}{l}9.20 \\
(2.71)^{* * *}\end{array}$ & 6.53 \\
\hline $\begin{array}{l}\text { No. Observations } \\
\text { Proportion Spending Money }\end{array}$ & $\begin{array}{l}465 \\
1.0\end{array}$ & $\begin{array}{l}500 \\
0.08\end{array}$ & $\begin{array}{l}500 \\
0.71\end{array}$ & \\
\hline
\end{tabular}

\footnotetext{
*Indicates statistical significance at or below the 0.10 level based on a two-tailed $t$-test.

** Indicates statistical significance at or below the 0.05 level based on a two-tailed t-test.

***Indicates statistical significance at or below the 0.01 level based on a two-tailed $t$-test.
} 
to casino gambling. The results also suggest that money spent in casinos may have been diverted from other tourist activities in the area.

\section{Casino Expenditures}

Table 5 shows the per-visit casino spending patterns across groups. Spending is divided into gambling and nongambling expenditures. Nongambling expenditures are further categorized into money spent shopping within the casino and money spent on food and beverages in the casino.

The first column reveals patterns in gambling expenditures across groups. Although potentially truncated at zero, all respondents reported spending at least $\$ 1$ on gambling; thus, ordinary least squares remains unbiased. All else equal, higher-income visitors gamble more money per visit, about $\$ 13$ for every $\$ 10,000$ in additional income. Although from Table 1 we see that the proportion of gamblers who reported being unemployed was only 2 percent, those gamblers spent about an additional $\$ 89$ per visit. It could be that this segment of the unemployed views gambling as an investment-an attempt to increase income-rather than as an entertainment expense. Alternatively, with greater leisure they may simply spend more time in the casino per visit. Finally, out-of-state visitors spent on average an additional $\$ 42$ per visit.

In contrast to gambling expenditures, not all respondents reported spending money on shopping within the casino or on food and beverages, making the dependent variable truncated at zero. The truncation makes ordinary least squares biased, indicating that the Tobit estimator is appropriate. Expenditures on shopping and food and beverages are separately regressed on the same respondent characteristics. However, convergence with maximum likelihood was only achieved for food and beverage expenditures. Because of nonconvergence, then, ordinary least squares is used to examine shopping expenditures within the casino.

Females reported spending less money shopping in casinos, about $90 \propto$ less per visit. Both whites and Native Americans reported spending less than other nonwhite minorities. Again, those from out-of-state reported spending more, $90 \varnothing$ per visit.

Tobit estimates for food and beverage spending are reported in the third column of Table 5. These estimates are not the marginal effects (i.e., slopes), which are reported separately in the fourth column. The marginal effects are obtained by multiplying the Tobit estimates by the proportion of money spent on food and beverages, which is the probability of the noncensored region (see McDonald and Moffitt 1980). The sole variable significantly related to food and beverage spending is out-of-state residence, with nonresidents spending about an additional $\$ 6.50$ per visit.

\section{Noncasino Expenditures}

Patterns in expenditures occurring outside the casinos are shown in Table 6. Expenditures are categorized into those for lodging, food and beverages, and all 
other expenditures. Other expenditures include shopping outside the casino, movies, and other forms of entertainment. Tobit estimation is used for all expenditure categories.

\section{TABLE 6}

Noncasino Spending

(absolute value of t-statistic in parentheses)

\begin{tabular}{|c|c|c|c|c|c|c|}
\hline \multirow[t]{2}{*}{$\begin{array}{l}\text { Independent/Depende } \\
\text { Variables }\end{array}$} & \multicolumn{2}{|c|}{$\begin{array}{ll}\text { Lodging } \\
\text { (TOBIT) }\end{array}$} & \multicolumn{2}{|c|}{$\begin{array}{c}\text { Food \& Beverage } \\
\text { (TOBIT) }\end{array}$} & \multicolumn{2}{|c|}{$\begin{array}{c}\text { Other Expenditures } \\
\text { (TOBIT) }\end{array}$} \\
\hline & Coefficient & Slope & Coefficient & Slope & Coefficient & Slope \\
\hline Constant & $\begin{array}{l}-590.82 \\
(3.40)^{* * *}\end{array}$ & & $\begin{array}{l}-80.43 \\
(3.20)^{* * *}\end{array}$ & & $\begin{array}{r}-186.31 \\
(1.28)\end{array}$ & \\
\hline Gender $($ Female $=1)$ & -67.47 & & -5.91 & & -10.58 & \\
\hline & $(1.63)$ & -5.40 & $(0.72)$ & -1.06 & $(0.18)$ & -0.53 \\
\hline Age & $\begin{array}{c}0.41 \\
(0.25)\end{array}$ & 0.03 & $\begin{array}{l}-0.43 \\
(1.21)\end{array}$ & -0.08 & $\begin{array}{l}5.66 \\
(2.11)^{* *}\end{array}$ & 0.28 \\
\hline Race (Caucasian=1) & $\begin{array}{l}212.40 \\
(1.65)^{*}\end{array}$ & 17.00 & $\begin{array}{l}11.85 \\
(0.10)\end{array}$ & 2.13 & $\begin{array}{r}-63.08 \\
(0.69)\end{array}$ & -3.15 \\
\hline Native American & $\begin{array}{l}361.97 \\
(2.57)^{* * *}\end{array}$ & 28.96 & $\begin{array}{l}25.00 \\
(1.18)\end{array}$ & 4.50 & $\begin{array}{r}-65.72 \\
(0.52)\end{array}$ & -3.29 \\
\hline Unemployed & $\begin{array}{r}-768.30 \\
(0.08)\end{array}$ & -61.46 & $\begin{array}{l}52.56 \\
(2.30)^{* *}\end{array}$ & 9.46 & $\begin{array}{l}34.93 \\
(0.40)\end{array}$ & 1.75 \\
\hline Retired & $\begin{array}{c}0.81 \\
(1.55)\end{array}$ & 0.06 & $\begin{array}{l}-6.99 \\
(0.62)\end{array}$ & -1.26 & $\begin{array}{r}-29.84 \\
(0.17)\end{array}$ & 1.49 \\
\hline Income & $\begin{array}{l}-4.85 \\
(0.55)\end{array}$ & -0.39 & $\begin{array}{l}5.12 \\
(2.30)^{* *}\end{array}$ & 0.92 & $\begin{array}{c}7.71 \\
(0.67)\end{array}$ & 0.39 \\
\hline $\begin{array}{l}\text { Distance } \\
\quad(50-100 \text { miles })\end{array}$ & $\begin{array}{l}110.28 \\
(1.97)^{* *}\end{array}$ & 8.82 & $\begin{array}{l}18.28 \\
(1.68)^{*}\end{array}$ & 3.29 & $\begin{array}{r}-163.21 \\
(1.31)\end{array}$ & -8.16 \\
\hline $\begin{array}{l}\text { Distance } \\
\text { (Over } 100 \text { miles) }\end{array}$ & 210.36 & 16.83 & $\begin{array}{l}47.96 \\
(4.74)^{* * *}\end{array}$ & 8.63 & $\begin{array}{l}177.01 \\
(2.58)^{* * *}\end{array}$ & 8.85 \\
\hline Out of State & $\begin{array}{l}129.33 \\
(3.76)^{* * *}\end{array}$ & 10.35 & $\begin{array}{c}5.69 \\
(0.73)\end{array}$ & 1.02 & $\begin{array}{l}82.73 \\
(1.71)^{*}\end{array}$ & 4.14 \\
\hline $\begin{array}{l}\text { No. Observations } \\
\text { Proportion Spending }\end{array}$ & 500 & & 500 & & 500 & \\
\hline Money & 0.08 & & 0.18 & & 0.05 & \\
\hline
\end{tabular}

\footnotetext{
*Indicates statistical significance at or below the 0.10 level based on a two-tailed $t$-test.

**Indicates statistical significance at or below the 0.05 level based on a two-tailed t-test.

*** Indicates statistical significance at or below the 0.01 level based on a two-tailed $t$-test.
}

Not surprisingly, those who traveled farther spent more on lodging. Wisconsin residents who traveled between 50 and 100 miles spent almost $\$ 9$ per night more than those who lived closer. Residents traveling over 100 miles spent an additional $\$ 17$ per night. Nonresidents spent over $\$ 10$ more than residents. Thus, a nonresident who traveled more than 100 miles spent about $\$ 27$ dollars more per night than a resident that traveled less than 50 miles. Race also was a significant factor.

Those traveling farther also spent more on food and beverages outside the casino, though residency was insignificant. Higher-income individuals spent more per visit, about $\$ 1$ for every $\$ 10,000$ in additional annual income. After controlling for income, those who were unemployed surprisingly spent over $\$ 9$ more per visit. As suggested before, perhaps the unemployed spent more time each visit, thus incurring greater food and beverage expenditures.

Regarding other expenditures (shopping and entertainment), age is positively related, while income and unemployment status were insignificant. Traveling a 
greater distance and being a nonresident significantly increased other noncasino expenditures. Recall, however, that those who traveled over 100 miles were less likely to report that visiting casinos was the purpose of the trip.

\section{Expenditure Substitution Patterns}

We saw in Table 1 that many households reallocated their budgets or had their savings reduced. How the effects on savings and spending on nonentertainment (necessity) goods differed across groups is presented in Table 7. The only significant result in column one is that those with higher incomes were less likely to have their savings reduced as a result of gambling at casinos. This suggests that higher-income individuals were more likely to reduce other expenditures than reduce their savings. Lower-income households most likely had fewer items from which they could reduce their expenditures.

\section{TABLE 7}

Nonentertainment Expenditure Substitutions

(absolute value of $\mathrm{t}$-statistic in parentheses)

\begin{tabular}{lccc}
\hline $\begin{array}{l}\text { Independent/Dependent } \\
\text { Variables }\end{array}$ & $\begin{array}{c}\text { Save More } \\
\text { (LOGIT) }\end{array}$ & $\begin{array}{c}\text { Groceries } \\
\text { (LOGIT) }\end{array}$ & $\begin{array}{c}\text { Clothes } \\
(\text { LOGIT) }\end{array}$ \\
\hline Constant & 0.20 & -1.42 & -0.39 \\
& $(0.30)$ & $(1.38)$ & $(0.54)$ \\
Gender (Female=1) & 0.09 & 0.34 & 0.94 \\
& $(0.37)$ & $(0.83)$ & $(3.40)^{* * *}$ \\
Age & -0.02 & $0.9 \mathrm{E}-02$ & -0.15 \\
& $(1.46)$ & $(0.54)$ & $(1.35)$ \\
Race (Caucasian=1) & -0.14 & -0.96 & -0.91 \\
Native American & $(0.35)$ & $(1.77)^{*}$ & $(2.21)^{* *}$ \\
& -0.26 & -0.85 & -0.11 \\
Unemployed & $(0.45)$ & $(0.97)$ & $(0.22)$ \\
& -1.08 & -0.90 & -1.80 \\
Retired & $(1.30)$ & $(0.78)$ & $(1.61)$ \\
& -0.15 & -0.20 & 0.35 \\
Income & $(0.48)$ & $(0.42)$ & $(1.07)$ \\
& -0.10 & -0.27 & -0.04 \\
Distance (50-100 miles) & $(1.72)^{*}$ & $(2.37)^{* * *}$ & $(0.07)$ \\
& -0.32 & -0.14 & -0.25 \\
Distance (Over 100 miles) & $(1.03)$ & $(0.29)$ & $(0.77)$ \\
& -0.09 & -0.36 & -0.56 \\
Out-of-State & $(0.29)$ & $(0.66)$ & $(1.58)$ \\
& -0.61 & 0.74 & -0.07 \\
No. Observations & $(1.51)$ & $(1.30)$ & $(0.16)$ \\
Chi-Squared Statistic & 495 & 495 & 495 \\
T. & 12.09 & $16.79 \mathrm{a}$ & $29.44^{\mathrm{c}}$ \\
\hline
\end{tabular}

\footnotetext{
aStatistically significant at the .10 level based on the chi-squared test

b Statistically significant at the .05 level based on the chi-squared test

CStatistically significant at the .01 level based on the chi-squared test

*Indicates statistical significance at or below the 0.10 level based on a two-tailed $t$-test.

**Indicates statistical significance at or below the 0.05 level based on a two-tailed t-test.

***Indicates statistical significance at or below the 0.01 level based on a two-tailed t-test.
}

Lower-income individuals also were more likely to have reduced their purchases of groceries because of casino gambling (from column 2). Correspondingly, non-Native American minorities were more likely to have reduced their purchases of groceries and clothing (columns 2 and 3). Females also reported reducing purchases of clothing because of gambling expenditures. 
Further insight into the household budget reallocations can be obtained by looking at casino gambling-entertainment substitutions in Table 8. From columns 1 and 2, we see that higher-income individuals were more likely to gamble somewhere else or travel if the casino site did not exist. Older individuals and nonresidents also were more likely to go elsewhere to gamble if the existing casino were not there. Wisconsin residents who traveled farther were not more likely to indicate that they would gamble elsewhere if the current site did not exist than those who lived closer. Those who traveled more than 100 miles were more likely to indicate, though, that they would travel more if casino gambling did not exist.

Expenditures by both Wisconsin residents who traveled more than 100 miles and nonresidents on dining out were less affected by casino gaming. Those living closer to the casinos were more likely to reduce their visits to area eating establishments. Only younger individuals reported being more likely to go to more movies in the absence of casino gambling (column 4).

\section{TABLE 8}

Entertainment Expenditure Substitutions (absolute value of $\mathrm{t}$-statistic in parentheses)

\begin{tabular}{|c|c|c|c|c|}
\hline $\begin{array}{l}\text { Independent/Dependent } \\
\text { Variables }\end{array}$ & $\begin{array}{l}\text { Other Casinos } \\
\text { (LOGIT) }\end{array}$ & $\begin{array}{l}\text { Other Travel } \\
\text { (LOGIT) }\end{array}$ & $\begin{array}{l}\text { Dine Out } \\
\text { (LOGIT) }\end{array}$ & $\begin{array}{l}\text { Movies } \\
\text { (LOGIT) }\end{array}$ \\
\hline Constant & $\begin{array}{l}-1.60 \\
(2.58)^{* * *}\end{array}$ & $\begin{array}{l}-1.38 \\
(2.13)^{* *}\end{array}$ & $\begin{array}{l}-1.00 \\
(1.51)\end{array}$ & $\begin{array}{l}-0.78 \\
(0.97)\end{array}$ \\
\hline Gender $($ Female $=1)$ & $\begin{array}{l}-0.30 \\
(1.47)\end{array}$ & $\begin{array}{l}-0.10 \\
(0.47)\end{array}$ & $\begin{array}{l}0.08 \\
(0.37)\end{array}$ & $\begin{array}{c}0.24 \\
(0.85)\end{array}$ \\
\hline Age & $\begin{array}{l}0.02 \\
(1.74)^{*}\end{array}$ & $\begin{array}{l}-0.1 \mathrm{E}-02 \\
(0.12)\end{array}$ & $\begin{array}{l}0.2 \mathrm{E}-02 \\
(0.25)\end{array}$ & $\begin{array}{l}-0.02 \\
(1.71)^{*}\end{array}$ \\
\hline Race (Caucasian=1) & $\begin{array}{c}-0.30 \\
(-0.77)\end{array}$ & $\begin{array}{l}0.07 \\
(0.17)\end{array}$ & $\begin{array}{c}0.51 \\
(1.14)\end{array}$ & $\begin{array}{c}0.04 \\
(0.07)\end{array}$ \\
\hline Native American & $\begin{array}{l}-0.59 \\
(1.08)\end{array}$ & $\begin{array}{l}-0.37 \\
(0.62)\end{array}$ & $\begin{array}{l}0.27 \\
(0.45)\end{array}$ & $\begin{array}{l}-0.11 \\
(0.15)\end{array}$ \\
\hline Unemployed & $\begin{array}{l}-0.3 \mathrm{E}-03 \\
(0.00)\end{array}$ & $\begin{array}{l}-0.37 \\
(0.45)\end{array}$ & $\begin{array}{l}-1.57 \\
(1.45)\end{array}$ & $\begin{array}{l}-0.87 \\
(0.79)\end{array}$ \\
\hline Retired & $\begin{array}{l}0.25 \\
(0.96)\end{array}$ & $\begin{array}{l}0.35 \\
(1.25)\end{array}$ & $\begin{array}{c}0.08 \\
(0.31)\end{array}$ & $\begin{array}{l}0.35 \\
(0.92)\end{array}$ \\
\hline Income & $\begin{array}{l}0.09 \\
(2.00)^{* *}\end{array}$ & $\begin{array}{l}0.09 \\
(1.87)^{*}\end{array}$ & $\begin{array}{l}-0.07 \\
(1.41)\end{array}$ & $\begin{array}{l}0.01 \\
(0.24)\end{array}$ \\
\hline Distance (50-100 miles) & $\begin{array}{c}0.13 \\
(0.51)\end{array}$ & $\begin{array}{c}0.42 \\
(1.58)\end{array}$ & $\begin{array}{c}0.24 \\
(0.96)\end{array}$ & $\begin{array}{l}-0.28 \\
(0.76)\end{array}$ \\
\hline Distance (Over 100 miles) & $\begin{array}{l}0.18 \\
(0.70)\end{array}$ & $\begin{array}{l}0.53 \\
(2.04)^{* *}\end{array}$ & $\begin{array}{l}-0.67 \\
(2.28)^{* *}\end{array}$ & $\begin{array}{l}-0.50 \\
(1.30)\end{array}$ \\
\hline Out-of-State & $\begin{array}{l}0.77 \\
(2.47)^{* * *}\end{array}$ & -0.55 & $\begin{array}{l}-0.99 \\
(2.32)^{* *}\end{array}$ & $\begin{array}{l}-0.54 \\
(1.00)\end{array}$ \\
\hline $\begin{array}{l}\text { No. Observations } \\
\text { Chi-Squared Statistic }\end{array}$ & $\begin{array}{l}495 \\
24.4^{\mathrm{c}}\end{array}$ & $\begin{array}{l}495 \\
14.96\end{array}$ & $\begin{array}{l}495 \\
34.8^{\mathrm{c}}\end{array}$ & $\begin{array}{l}495 \\
8.8\end{array}$ \\
\hline
\end{tabular}

\footnotetext{
aStatistically significant at the .10 level based on the chi-squared test

b Statistically significant at the .05 level based on the chi-squared test

'Statistically significant at the .01 level based on the chi-squared test

*Indicates statistical significance at or below the 0.10 level based on a two-tailed $t$-test.

**Indicates statistical significance at or below the 0.05 level based on a two-tailed $t$-test.

***Indicates statistical significance at or below the 0.01 level based on a two-tailed t-test.
} 


\section{SUMMARY AND CONCLUSION}

Although there are significant estimated economic benefits to tribes of Native American casino gambling, the result for the rest of the state is less sanguine. There is a large transfer of funds from the rest of Wisconsin to the area economies where the casinos are located. There is evidence of displacement of tourist expenditures elsewhere in the state. Since many visitors would travel to the area in the absence of casinos, area businesses such as eating establishments may lose business rather than gain business. Moreover, those living closer to casinos are the most frequent visitors and they also report substituting gambling expenditures for those on other goods and services.

Unemployed individuals reported spending more on gambling and associated expenses per visit than others. Lower-income individuals were most likely to have their savings reduced and spend less on groceries because of casino gambling. Even when controlling for income, non-Native American minorities were more likely to report that gambling expenditures reduced their expenditures on groceries and clothing.

Given the moral controversy surrounding gambling, future economic impact assessments of casino gambling should examine the relative impacts of gambling on other businesses in the state and the relative hardship that results for various demographic groups. In the present study, there were gains in the reservation economies to offset losses in other segments of the state. However, for corporate casino gambling (with the likely flow of profits outside the region), and less geographically remote casinos (with greater flows of labor income outside the area), there are likely to be less gains to the immediate area and state to offset the losses.

\section{APPENDIX}

\section{SURVEY QUESTIONS USED IN THE ANALYSIS}

1. How far is the town in which you live from this casino?

less than 35 miles

between 35 and 50 miles

between 50 and 100 miles

more than 100 miles

2. Was visiting the casino the primary purpose of your trip?

Yes

No

3. Is this your first visit to the casino?

Yes

No

4. How frequently do you visit this casino in a year?

5. Would you be visiting this area if there was not a gaming facility here? Yes No 
6. How much do you individually plan to spend on gambling during your entire visit?

7. During your visit, approximately how much money did you spend or plan to spend on:

food and beverage within the casino

food and beverage outside the casino

lodging

shopping within the casino shopping outside the casino shows/movies, other entertainment transportation cost within the area tour bus cost

8. In the absence of gambling in Wisconsin, how else would you spend your gaming money:

go out to movies and shows more often

dine out more often

buy more groceries

travel

shop for clothes

save more

visit casinos in other states

9. Gender: Male $=0$, Female $=1$

10. In what year were you born?

11. Race:

White

African American

Asian

Hispanic

Native American

12. What is your primary occupation?

13. Which of these numerical categories corresponds to your annual household income before taxes? less than 10,000 $30,000-39,999$ $60,000-69,999$ 90,000-99,999
$10,000-19,999$

$40,000-49,000$

70,000-79,999

more than 100,000
20,000-29,999 50,000-59,999 80,000-89,999 


\section{REFERENCES}

Anders, G.C. "Native American Casino Gambling in Arizona: A Case Study of the Fort McDowell Reservation." Journal of Gambling Studies 12 (1996), 253-267. Anders, G.C., D. Siegel, and M. Yacoub. "Does Indian Casino Gambling Reduce State Revenues?" Contemporary Economic Policy 16 (1998), 347-355.

Blair, B.F., R.K. Schwer, and C. J. Waddoups. "Gambling as an Economic Development Strategy: The Neglected Issue of Job Satisfaction and Nonpecuniary Income." The Review of Regional Studies 28 (1998), 47-62.

Blevins, A., and K. Jensen. "Gambling as a Community Development Quick Fix." Annals of the American Academy of Political and Social Science 556 (1998), 109-123. Boreham, P., M. Dickerson, and B. Harley. "What are the Social Costs of Gambling? The Case of the Queensland Machine Gaming Industry." Australian Journal of Social Issues 31 (1996), 425-442.

Borg, M.O., P.M. Mason, and S.L. Shapiro. "An Economic Comparison of Gambling Behavior in Atlantic City and Las Vegas." Public Finance Quarterly 18 (1990), 291-312.

."The Incidence of Taxes on Casino Gambling: Exploiting the Tired and

Poor." American Journal of Economics and Sociology 50 (1991), 323-332.

Christiansen, E. "Gambling and the American Economy." Annals of the American Academy of Political and Social Science 556 (1998), 36-52.

d'Hautessere, Anne-Marie. "Foxwoods Casino Report: An Unusual Experiment in Economic Development." Economic Geography Extra Issue (1998), 112-121.

Eadington, W. "The Economics of Casino Gambling." Journal of Economic Perspectives 13 (1999), 173-192.

Friedman, J., S. Hakim, and J. Weinblatt. "Casino Gambling as a 'Growth Pole' Strategy and its Effect on Crime." Journal of Regional Science 29 (1989), 615-623.

Gazel, R. "The Economic Impacts of Casino Gambling at the State and Local Levels." Annals of the American Academy of Political and Social Science 556 (1998), 66-84.

Gazel, R., W.N. Thompson, and D.S. Rickman. "The Economic Impacts of Native American Gaming in Wisconsin." Gaming Research and Review Journal 2 (1995), 43-62.

Giacopassi, D., and B.G. Still. "Assessing the Impact of Casino Gambling on Crime in Mississippi." American Journal of Criminal Justice 18 (1993), 117-131.

Goodman, R. Legalized Gambling as a Strategy for Economic Development. Amherst, MA: Center for Economic Development, 1994.

Grinols, E. "Bluff or Winning Hand? Riverboat Gambling and Regional Employment and Unemployment." Illinois Business Review 51 (1994), 8-11.

Grinols, E., and J.D. Omorov. "Who Loses When Casinos Win?" Illinois Business Review 53 (1996), 7-11.

Gross, M. "Legal Gambling as a Strategy for Economic Development." Economic Development Quarterly 12 (1998), 203-213.

Henriksson, L.E. "Hardly a Quick Fix: Casino Gambling in Canada." Canadian Public Policy 22 (1996), 116-128. 
Hsing, Y. "An Analysis of Arrests Regarding Illegal Drugs: The Determinants and Policy Implications." American Journal of Economics and Sociology 55 (1996), 53-60.

Layton, A., and A. Worthington. "The Impact of Socio-Economic Factors on Gambling Expenditure." International Journal of Social Economics 26 (1999), 430-440.

Lesieur, H.R. "Costs and Treatment of Pathological Gambling." Annals of the American Academy of Political and Social Science 556 (1998), 153-171.

Madhusudhan, R.G. "Betting on Casino Revenues: Lessons from State Experiences." National Tax Journal 49 (1996), 401-412.

Mason, P.M., S.L. Shapiro, and M.O. Borg. "Gambling Tax Incidence for Three Groups of Las Vegas Gamblers." Applied Economics 21 (1989), 1267-1277.

Mason, P.M., and H. Stranahan. "The Effects of Casino Gambling on State Tax Revenue." Atlantic Economic Journal 24 (1996), 336-348.

McDonald, J., and R. Moffitt. "The Uses of Tobit Analysis." The Review of Economics and Statistics 62 (1980), 318-321.

Miller, W., and M. Schwartz. "Casino Gambling and Street Crime." Annals of the American Academy of Political and Social Science 556 (1998), 124-137

Persky, J. "Impact Studies, Cost-Benefit Analysis \& Casinos." Journal of Gambling Studies 11 (1995), 349-360.

Przybylski, M., D. Felsenstein, D. Freeman, and L. Littlepage. "Does Gambling Complement the Tourist Industry? Some Empirical Evidence of Import Substitution and Demand Displacement." Tourism Economics 4 (1998), 213-231.

Rephann, T.J., M. Dalton, A. Stair, and A. Isserman. "Casino Gambling as an Economic Development Strategy." Tourism Economics 3 (1997), 161-183.

Rivenbark, W.C. "The Tax Incidence of Casino Gaming in Mississippi." Public Finance Review 26 (1998), 583-598.

Thompson, W., R. Gazel, and D.S. Rickman. "The Social and Legal Costs of Compulsive Gambling." Gaming Law Review 1 (1997), 81-89.

Walker, D., and J. Jackson. "New Goods and Economic Growth: Evidence from Legalized Gambling." The Review of Regional Studies 28 (1998), 47-69. 